\title{
Article
}

\section{Modeling of Copper Adsorption on Mesoporous Carbon CMK-3: Response Surface Design}

\author{
Zeinab Ezzeddine ${ }^{1,2, *}$, Isabelle Batonneau-Gener ${ }^{1}$ and Yannick Pouilloux ${ }^{1}$ \\ 1 Institut de Chimie des Milieux et Matériaux de Poitiers (IC2MP)—UMR 7285, Poitiers University, \\ 86073 Poitiers, France; isabelle.gener@univ-poitiers.fr (I.B.-G.); yannick.pouilloux@univ-poitiers.fr (Y.P.) \\ 2 Platform for Research and Analysis in Environmental Sciences, Lebanese University, \\ P.O. Box 6573/14 Beirut, Lebanon \\ * Correspondence: zeinab.ezzeddine@univ-poitiers.fr
}

Received: 15 August 2018; Accepted: 11 October 2018; Published: 14 October 2018

\begin{abstract}
CMK-3 mesoporous carbon was nanocast from SBA-15 silica. The obtained carbon was characterized by nitrogen sorption isotherms, X-ray diffraction and transmission electron microscopy (TEM). The batch adsorption tests were done at constant $\mathrm{pH}$ taking into account the initial metal ion concentration, adsorbent mass and temperature. A statistical study using a response surface design method was done to develop a mathematical model to predict copper adsorption on CMK-3 as a function of the mentioned experimental factors. It was found that all these parameters are significant, and copper concentration has the greatest effect on adsorption among them. Moreover, the obtained model proved to be adequate in predicting copper adsorption on CMK-3 and its performance under different experimental conditions.
\end{abstract}

Keywords: mesoporous CMK-3; copper; adsorption; response surface design

\section{Introduction}

The direct discharge of industrial and domestic wastewater into the environment is responsible for the severe pollution of water sources today. Among various pollutants ejected, heavy metals are among the most dangerous inorganic contaminants since they persist in nature, leading to their accumulation in living organisms [1]. Copper is commonly found in discharged effluents. Copper pipes are used in plumbing, leading to elevated copper levels in water. This affects human health leading to vomiting, diarrhea, nausea and stomach cramps. Moreover, copper may damage the liver and lead to kidney diseases [2]. Different techniques are used to eliminate heavy metal ions from water, such as chemical precipitation, membrane filtration, adsorption and ion exchange. Adsorption is considered a promising method because it is simple, effective, and many adsorbents are available. Many studies have been done on different types of materials [3,4] such as ion-exchange resins, zeolites, activated carbon and modified mesoporous silica. Since the discovery of ordered mesoporous carbons (OMCs), they have been attracting interest in various application fields including adsorption [5]. OMCs are synthesized by carbon source polymerization in mesoporous silica templates. They are highly stable both mechanically and hydrothermally [6,7]. In addition, nanocast carbons exhibit large surface areas and pore volumes, as well as uniform pore sizes [8-10]. Several researchers proved the effectivity of OMC in removal of heavy metals from water [11,12]. Based on what was previously mentioned, this study intends to investigate the efficiency of CMK-3 in removing copper from water. Several factors affect the performance of any adsorbent, including CMK-3. Metal ion concentration, adsorbent mass and temperature greatly influence copper removal. In the present work, a statistical study using the response surface method was performed for developing a mathematical model to predict copper adsorption on CMK-3 as a function of metal ion concentration, adsorbent mass and 
temperature. This method is a multivariate technique based on a set of mathematical and statistical approaches in order to fit empirical models to the obtained experimental data.

\section{Materials and Methods}

\subsection{Chemicals}

Pluronic P123 (EO20PO70EO20) was used as templates and tetraethylorthosilicate (TEOS 98\%) as the silica source for SBA-15. Hydrochloric acid $(\mathrm{HCl}, 37 \%)$, sulfuric acid $\left(\mathrm{H}_{2} \mathrm{SO}_{4}, 95 \%\right)$, sodium hydroxide $(\mathrm{NaOH})$, sucrose $\left(\mathrm{C}_{12} \mathrm{H}_{22} \mathrm{O}_{11}\right)$ and copper nitrate $\left(\mathrm{Cu}\left(\mathrm{NO}_{3}\right)_{2} \cdot 3 \mathrm{H}_{2} \mathrm{O}\right)$ were all obtained from Sigma Aldrich (St. Louis, MO, USA), and utilized without any further modification.

\subsection{SBA-15 and Mesoporous Carbon CMK-3 Synthesis}

Mesoporous carbon was made by applying SBA-15 silica as a cast based on the procedure described by Zhao et al. [13]. For SBA-15 synthesis, $4 \mathrm{~g}$ of P123 was dissolved in $30 \mathrm{~g}$ water and $120 \mathrm{~g}$ of $2 \mathrm{M} \mathrm{HCl}$ at $35^{\circ} \mathrm{C}$. After dissolution, $8.5 \mathrm{~g}$ of TEOS was added. The resulting mixture was stirred for $20 \mathrm{~h}$ at $35^{\circ} \mathrm{C}$, and then aged at $80^{\circ} \mathrm{C}$ overnight. The solid obtained was filtered, washed and dried. Calcination was performed at $500{ }^{\circ} \mathrm{C}$ for $6 \mathrm{~h}$ (heating ramp $1{ }^{\circ} \mathrm{C} / \mathrm{min}$ ). For CMK-3 synthesis, $1 \mathrm{~g}$ of SBA-15 powder was added to $1.5 \mathrm{~g}$ of sucrose dissolved in $5 \mathrm{~mL}$ of water and $0.09 \mathrm{~mL}$ of $18 \mathrm{M}$ $\mathrm{H}_{2} \mathrm{SO}_{4}$. The obtained mix was heated up for $6 \mathrm{~h}$ at $100{ }^{\circ} \mathrm{C}$ then the oven temperature was increased to $160{ }^{\circ} \mathrm{C}$ for another $6 \mathrm{~h}$. Another $1 \mathrm{~g}$ of sucrose dissolved in $5 \mathrm{~mL}$ of water and $0.05 \mathrm{~mL}$ of $18 \mathrm{M}$ $\mathrm{H}_{2} \mathrm{SO}_{4}$ were added to the previously obtained sample and it was thermally treated as described before. The silica-polymer composite was pyrolyzed for $6 \mathrm{~h}$ under nitrogen flow at $800^{\circ} \mathrm{C}$. Finally, the silica template was removed using $2 \mathrm{M} \mathrm{NaOH}[14]$.

\section{3. $S B A-15$ and $C M K-3$ Characterization}

Micromeritics TRISTAR sorptiometer was used to determine the textural properties through nitrogen sorption at $-196^{\circ} \mathrm{C}$. Before measurement, the materials were kept under vacuum at $350^{\circ} \mathrm{C}$ for 5 h. Empyrean X-ray diffractometer (Malvern Panalytical Ltd., Royston, UK) with $\mathrm{Cu} \mathrm{K} \alpha(\lambda=1.54 \AA)$ radiation was used to determine the (XRD) patterns from $0.65^{\circ}$ to $5^{\circ} 2 \theta$. The SBA- 15 and CMK-3 form was acquired by TEM (JEOL 2100 UHR at $200 \mathrm{kV}$, Tokyo, Japan).

\subsection{Adsorption in Batch Mode}

Copper nitrate salt was solvated in ultrapure water to obtain metal ion solutions. A mass (5, 10,20 and $30 \mathrm{mg}$ ) in g of CMK-3 was added to a volume (V) in L of metal ion solutions of a desired concentration between 10 and $300 \mathrm{ppm}\left(0.15\right.$ and $\left.4.7 \mathrm{mmol} \cdot \mathrm{L}^{-1}\right)$. The flask was continuously stirred for $120 \mathrm{~min}$ at $25^{\circ} \mathrm{C}, 35^{\circ} \mathrm{C}$ and $45^{\circ} \mathrm{C}$ at $300 \mathrm{rpm}$. Atomic Adsorption Spectrophotometer (AAS, Perkin Elmer AA200) determined the metal ion concentration at the end of each experiment. The removal efficiency was evaluated by Equation (1):

$$
R=\frac{C_{0}-C_{\mathrm{t}}}{C_{0}} \times 100,
$$

where $C_{0}$ and $C_{\mathrm{t}}$ are the heavy metal initial concentration and at time $t$ concentration. The $\mathrm{pH}$ effect was examined by adjusting the solution $\mathrm{pH}$ between 2 and 7 using either $\mathrm{HCl}$ or $\mathrm{NaOH}$ in order to determine the optimal $\mathrm{pH}$ range for performing the adsorption experiments. The adsorption tests at all temperatures were done in closed reactors in order to eliminate the effect of $\mathrm{CO}_{2}$ on the solution $\mathrm{pH}$. This was further proved by preparing blank copper solutions of different concentration $(2,8,10$ and $20 \mathrm{ppm}$ ), the concentration was measured for three successive days and no change was recorded, which eliminates the possibility of precipitation. 


\subsection{Response Surface Modeling}

Response surface design is widely used as a robust method to optimize a response $(y)$ that is influenced by independent variables $x_{i}$ [15]. Solution concentration $\left(x_{1}\right)$, temperature $\left(x_{2}\right)$ and mass of CMK-3 $\left(x_{3}\right)$ are the chosen independent variables, while the adsorption percentage $(y)$ of metal ions on carbon is considered the response (Table 1 ).

Table 1. The levels of independent variables.

\begin{tabular}{cccccc}
\hline \multirow{2}{*}{ Variables } & \multirow{2}{*}{ Code } & \multirow{2}{*}{ Symbol } & \multicolumn{4}{c}{ Levels } \\
\cline { 4 - 6 } & & & $\mathbf{- 1}$ & $\mathbf{0}$ & $\mathbf{+ 1}$ \\
\hline $\mathrm{Cu}^{2+}$ concentration $(\mathrm{ppm})$ & $\mathrm{A}$ & $\mathrm{C}$ & 50 & 150 & 300 \\
Temperature $\left({ }^{\circ} \mathrm{C}\right)$ & $\mathrm{B}$ & $\mathrm{T}$ & 25 & 35 & 45 \\
CMK-3 mass $(\mathrm{mg})$ & $\mathrm{C}$ & $\mathrm{M}$ & 5 & 10 & 20 \\
\hline
\end{tabular}

The percentage of adsorption is related to the independent variables by using the following second-order polynomial model:

$$
y=\beta_{0}+\sum_{i=1}^{3} \beta_{i} x_{i}+\sum_{i=1}^{3} \sum_{j=1}^{3} \beta_{i j} x_{i} x_{j}+\sum_{i=1}^{3} \beta_{i i} x_{i}^{2},
$$

where $y$ is the predicted response, and $x_{i}$ and $x_{j}$ are the independent variables. $\beta_{0}, \beta_{i}, \beta_{i j}$ and $\beta_{i i}$ are the regression coefficients for intercept, linear effect, double interaction and quadratic effect, respectively.

The equation in terms of coded factors can be used to make predictions about the response for given levels of each factor. By default, the high levels of the factors are coded as +1 and the low levels of the factors are coded as -1 . The coded equation is useful for identifying the relative impact of the factors by comparing the factor coefficients.

The final Equation (3) obtained using Design-Expert software (version 10.0.1) in terms of coded values is:

$$
\begin{aligned}
\% \text { Adsorption }= & +79.64-23.75 \mathrm{~A}+2.31 \mathrm{~B}+8.12 \mathrm{C}+1.82 \mathrm{AB}+0.35 \mathrm{AC}- \\
& 0.59 \mathrm{BC}-6.01 \mathrm{~A}^{2}+0.59 \mathrm{~B}^{2}-6.20 \mathrm{C}^{2} .
\end{aligned}
$$

The actual factors in Equation (4) can predict the response for given levels of each factor. The levels here must be specified in the original units for each factor:

$$
\begin{gathered}
\text { \% Adsorption }=+75.75-0.11 \mathrm{C}-0.33 \mathrm{~T}+4.04 \mathrm{M}+1.45 \times 10^{-3} \mathrm{CT}+ \\
3.76 \times 10^{-4} \mathrm{CM}-7.89 \times 10^{-3} \mathrm{TM}-3.84 \times 10^{-4} \mathrm{C}^{2}+5.86 \times 10^{-3} \mathrm{~T}^{2}-0.11 \mathrm{M}^{2} .
\end{gathered}
$$

\section{Results and Discussion}

\subsection{Physicochemical Characterizations}

Figure 1a presents the XRD diffractogram of SBA-15 and CMK-3 mesoporous carbon. It shows three diffraction peaks that are assigned to (100), (110) and (200) planes which indicate the 2D hexagonal symmetry $(P 6 \mathrm{~mm})$ of its template SBA-15 [16]. The interlayer distances for SBA-15 are 4.5, 2.6 and $2.3 \mathrm{~nm}$, while those of CMK-3 are 4.2, 2.5 and $2.2 \mathrm{~nm}$, which proves the agreement in lattice constant between SBA-15 and its carbon replica. The nitrogen sorption isotherms of SBA- 15 and mesoporous CMK-3 replica are given in Figure 1b. The isotherm of CMK-3 exhibited an IV type with $\mathrm{H}_{2}$ hysteresis loop which is similar to that of SBA-15. The isotherm exhibited a sharp step pressure increase at $\mathrm{P} / \mathrm{P}_{0}>0.35$ due to the narrower mesopores of CMK-3. The textural properties obtained from $\mathrm{N}_{2}$ sorption are listed in Table 2. The TEM image of SBA-15 and CMK-3 (Figure 1c) reveals that CMK-3 has also a hexagonal structure since it is an exact negative replica of the SBA-15 silica. 
a)

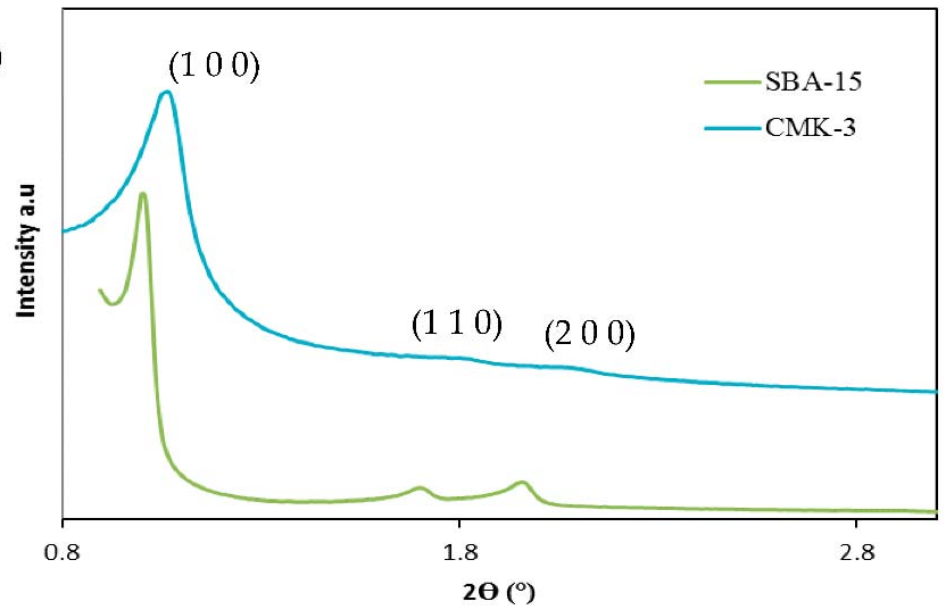

b)

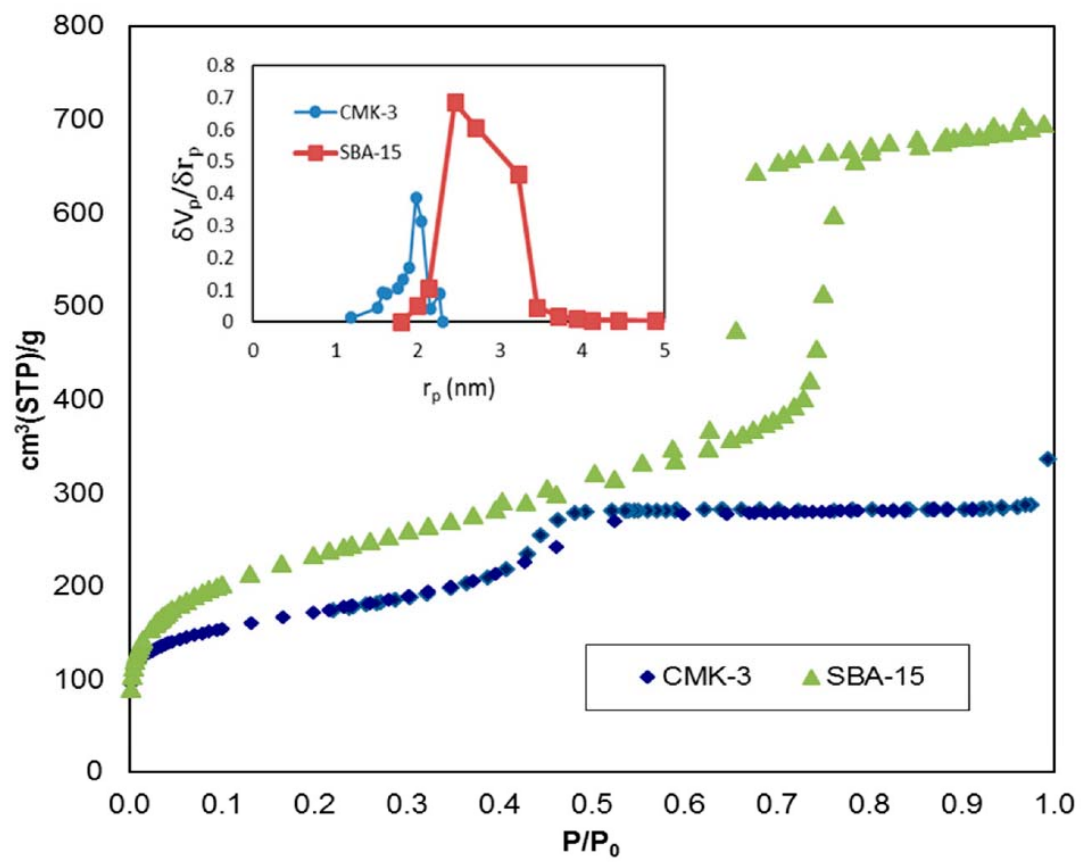

c)
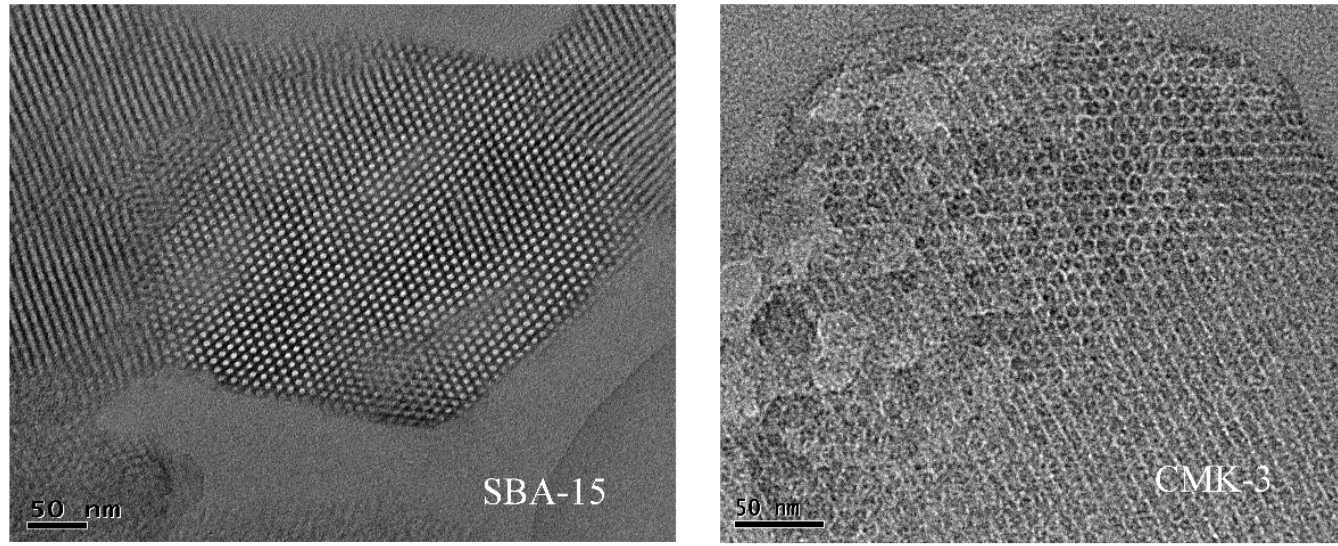

Figure 1. XRD diffractogram of SBA-15 and CMK-3 (a), nitrogen sorption isotherms (b) and TEM images (c). 
Table 2. Textural properties of SBA-15 and its CMK-3 replica.

\begin{tabular}{ccccc}
\hline Sample & S $_{\text {BET }}{ }^{\mathbf{a}}\left(\mathbf{m}^{\mathbf{2}} \cdot \mathrm{g}^{\mathbf{- 1}}\right)$ & Pore Size $^{\mathbf{b}} \mathbf{( n m )}$ & Mesopore Volume $\left.^{\mathbf{c}} \mathbf{( c m}^{\mathbf{3}} \cdot \mathrm{g}^{-\mathbf{1}}\right)$ & Micropore Volume $\left(\mathrm{cm}^{\mathbf{3}} \cdot \mathrm{g}^{-\mathbf{1}}\right)$ \\
\hline SBA-15 & 896 & 5.6 & 0.706 & 0.115 \\
CMK-3 & 621 & 4 & 0.4 & 0.033 \\
\hline
\end{tabular}

\subsection{Effect of Sorbent Mass}

The adsorbent mass optimization was performed by increasing carbon masses from $5 \mathrm{mg}$ to $30 \mathrm{mg}$ in $20 \mathrm{~mL}$ of $30 \mathrm{ppm} \mathrm{Cu}^{2+}$ solution for $120 \mathrm{~min}$ (Figure 2). The adsorption percentage increased as the CMK-3 mass increased from $5 \mathrm{mg}$ to $20 \mathrm{mg}$ to reach its maximum at $20 \mathrm{mg}$, so the levels of the independent variable $\mathrm{M}$ were set between 5 and $20 \mathrm{mg}$.

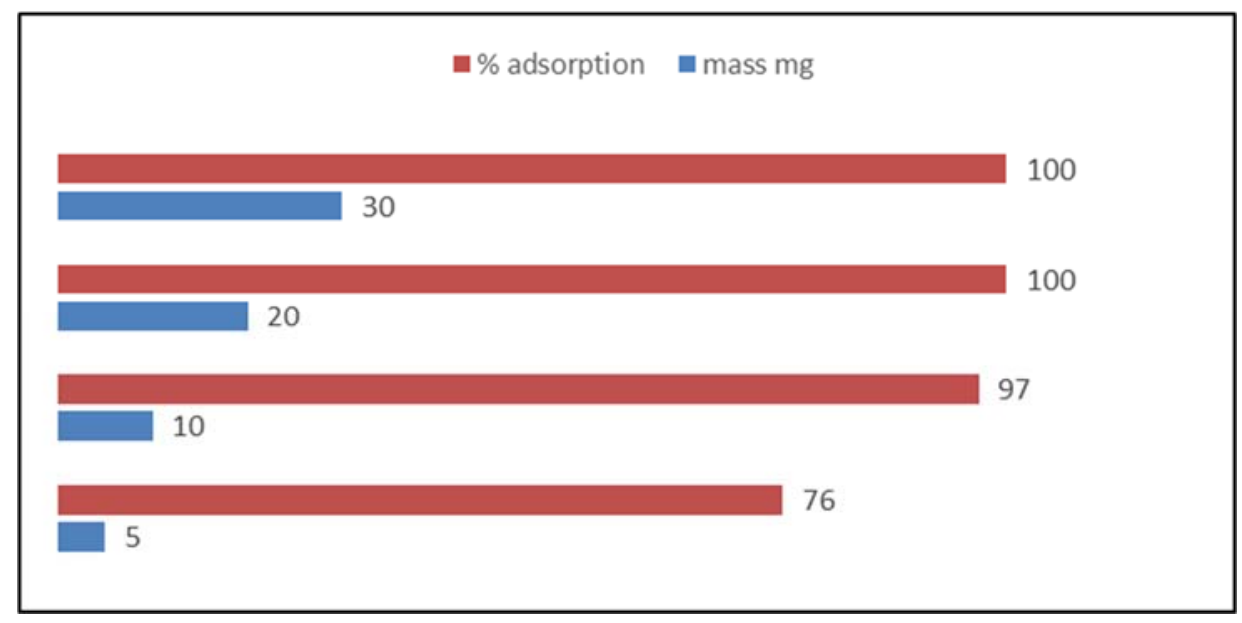

Figure 2. Mass effect on $\mathrm{Cu}^{2+}$ adsorption onto $\mathrm{CMK}-3$ (at $25^{\circ} \mathrm{C}, \mathrm{pH} 6$ and $\left[\mathrm{Cu}^{2+}\right]=30 \mathrm{ppm}$ ).

\section{3. $p H$ Effect}

The $\mathrm{pH}$ of the solution is critical for the adsorption process because it directly affects heavy metal ion speciation and CMK-3 surface charge. For this reason, the effect of $\mathrm{pH}$ was investigated by performing adsorption experiments at different values that ranged between 2 and 7 . The obtained results are presented in Figure 3.

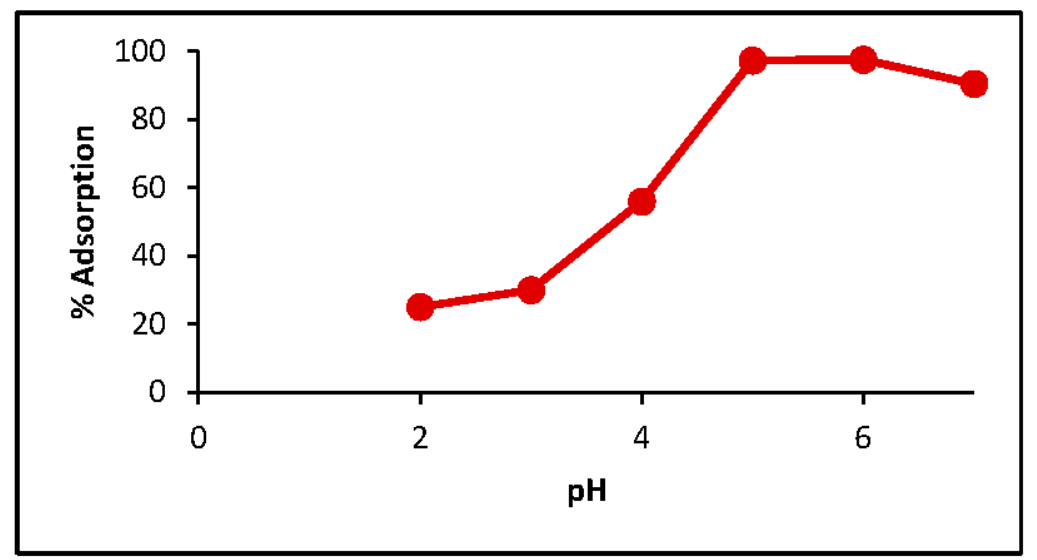

Figure 3. Effect of $\mathrm{pH}$ on $\mathrm{Cu}^{2+}$ adsorption onto $\mathrm{CMK}-3\left(\right.$ at $25^{\circ} \mathrm{C}, \mathrm{m}=20 \mathrm{mg}$ and $\left[\mathrm{Cu}^{2+}\right]=30 \mathrm{ppm}$ ).

As the above figure reveals, adsorption at low $\mathrm{pH}$ decreased due to two reasons. The first one is the competition between copper ions and hydronium ions, $\mathrm{H}_{3} \mathrm{O}^{+}$. The second reason for this decrease is the positive surface charge of CMK-3 at low $\mathrm{pH}$. The surface charge was determined by the $\mathrm{pH}$ shift method, which is described in detail in our previous work [7]. Herein, the CMK-3 zero-point charge 
was found to be 4.6, so above this $\mathrm{pH}$ its surface will be charged negatively, so it attracts the positively charged copper ions. The maximum adsorption was attained between $\mathrm{pH} 5$ and 6 , so the rest of the adsorption experiments were done at $\mathrm{pH}$ 6, since at this value the surface of $\mathrm{CMK}-3$ will be negatively charged and the copper ion species present will be $\mathrm{Cu}^{2+}$ and $\mathrm{CuOH}^{+}$[17], which both will be attracted by the adsorbent.

\subsection{Effect of Copper Concentration}

It is well known that metal ion concentration greatly affects the adsorption process on any type of adsorbent. In this study, copper ion concentration was varied between $10 \mathrm{ppm}$ and $300 \mathrm{ppm}$ to investigate the effect of metal ion concentration on copper uptake on CMK-3. The obtained results are shown in Figure 4. As ion concentration increased, the adsorption capacity increased as well to reach its maximum ( $250 \mathrm{mg} / \mathrm{g})$. Three copper concentration levels $(50,150$ and $300 \mathrm{ppm}$ ) were chosen for the independent variable $\mathrm{C}$.

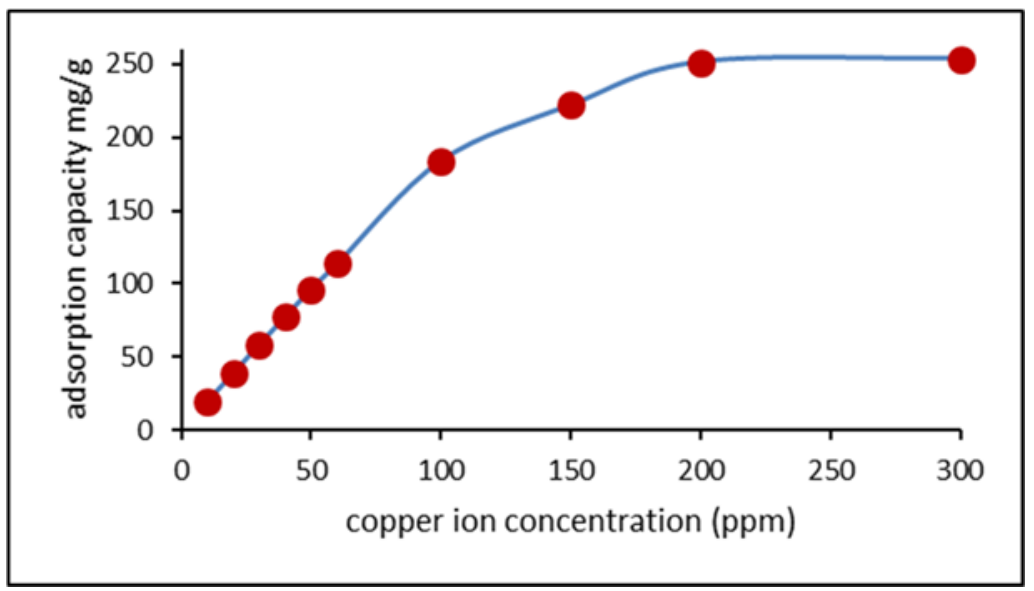

Figure 4. Concentration effect on $\mathrm{Cu}^{2+}$ adsorption (at $25^{\circ} \mathrm{C}, \mathrm{pH} 6$ and $\mathrm{m}=20 \mathrm{mg}$ ).

\subsection{Temperature Effect}

The effect of temperature on $\mathrm{Cu}^{2+}$ adsorption was investigated. The results are shown in Figure $5 \mathrm{a}$, where $\mathrm{Ce}$ is the copper concentration at equilibrium in ppm and qe is the adsorption capacity of CMK-3 in $\mathrm{mg} / \mathrm{g}$. The parameters for the thermodynamic study (free energy change $\left(\Delta \mathrm{G}^{\circ}\right)$, enthalpy change $\left(\Delta H^{\circ}\right)$ and entropy change $\left.\left(\Delta S^{\circ}\right)\right)$ were calculated. The obtained results showed a slight increase in copper adsorption as the temperature increased from $25^{\circ} \mathrm{C}$ to $45^{\circ} \mathrm{C}$. The Gibbs free energy change of the process is related to the distribution coefficient $\left(K_{d}\right)$ and was calculated as follows [18]:

$$
\begin{gathered}
\Delta G^{\circ}=-R T \ln K_{d}, \\
\Delta G^{\circ}=\Delta H^{\circ}-T \Delta S^{\circ}, \\
\log K_{d}=\frac{\Delta S^{\circ}}{2.303 R}-\frac{\Delta H^{\circ}}{2.303 R T} .
\end{gathered}
$$

$\Delta G^{\circ}\left(\mathrm{kJ} \cdot \mathrm{mol}^{-1}\right)$ is at temperature $T$ (in Kelvin), $\mathrm{R}$ is the universal gas constant $\left(8.314 \mathrm{~J} \cdot \mathrm{mol}^{-1} \cdot \mathrm{K}^{-1}\right)$. The values of $\Delta H^{\circ}$ and $\Delta S^{\circ}$ (Table 3) are calculated from the slope and intercept of van't Hoff plot of $\log K_{d}$ versus $1 / T$, respectively (Figure $5 b$ ). 

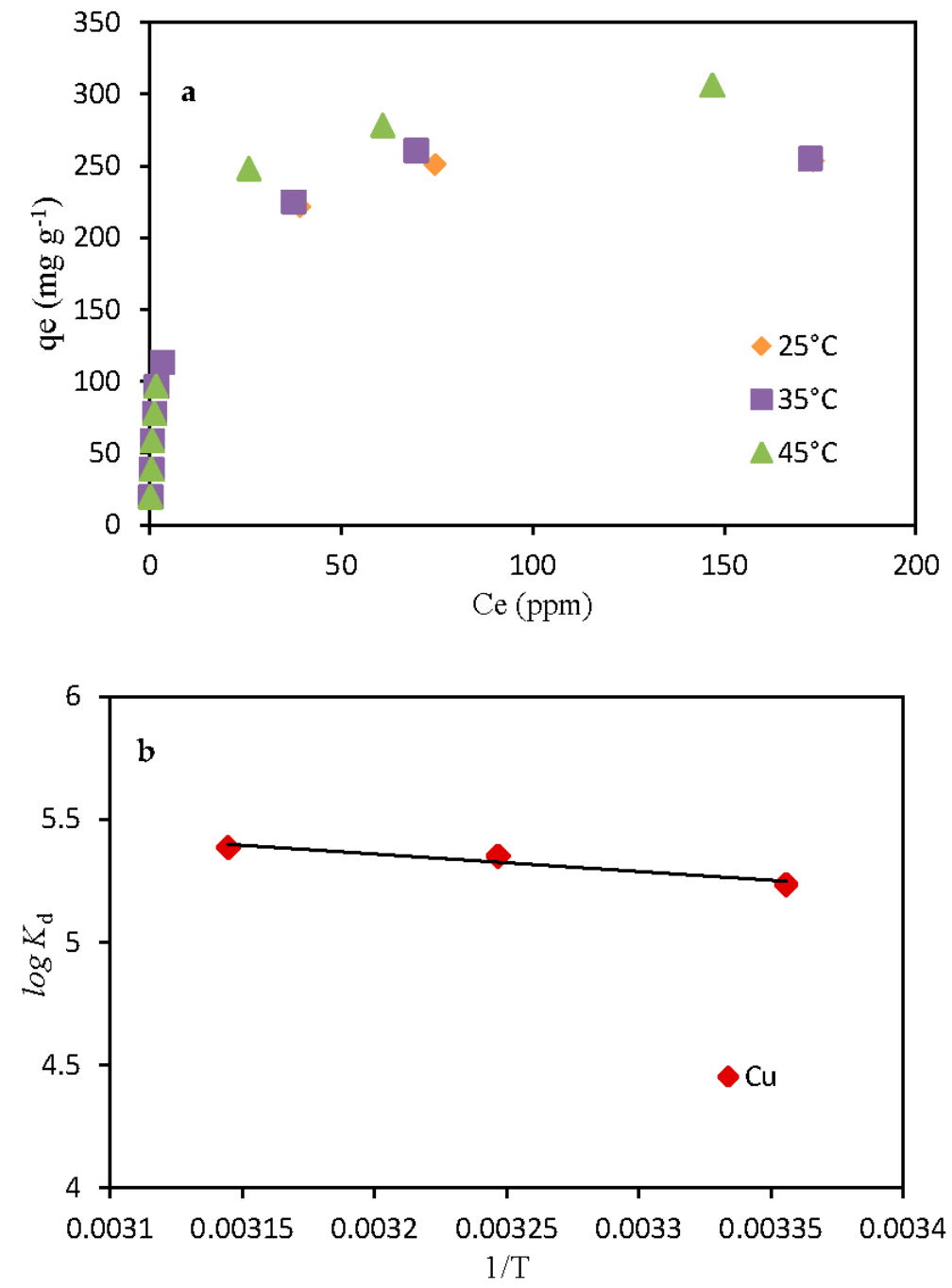

Figure 5. Temperature effect on copper adsorption (a) and plot of $\ln K_{d}$ versus $1 / T$ (b) (at pH 6 and $\mathrm{m}=20 \mathrm{mg})$.

Table 3. Thermodynamic parameters for $\mathrm{Cu}^{2+}$ adsorption on $\mathrm{CMK}-3$.

\begin{tabular}{|c|c|c|c|c|c|}
\hline Metal & $\Delta H^{\circ}\left(\mathrm{kJ} \cdot \mathrm{mol}^{-1}\right)$ & $\Delta S^{\circ}\left(\mathrm{J} \cdot \mathrm{K}^{-1} \cdot \mathrm{mol}^{-1}\right)$ & $T(\mathrm{~K})$ & $\Delta G^{\circ}\left(\mathrm{kJ} \cdot \mathrm{mol}^{-1}\right)$ & $R^{2}$ \\
\hline $\mathrm{Cu}^{2+}$ & 5.9 & 63.5 & $\begin{array}{l}298 \\
308 \\
318\end{array}$ & $\begin{array}{l}-12.9 \\
-13.7 \\
-14.2\end{array}$ & 0.923 \\
\hline
\end{tabular}

The $\Delta H^{\circ}$ positive value reveals that the adsorption process is endothermic. The adsorbent is highly porous, so the diffusion of ions inside the pores becomes more favorable as temperature increases. The negative values of $\Delta G^{\circ}$ indicate the spontaneous adsorption process; the values increased with temperature, so $\mathrm{Cu}^{2+}$ adsorption on $\mathrm{CMK}-3$ increased with temperature. The positive $\Delta S^{\circ}$ value confirms that the adsorption is favorable. $\mathrm{Cu}^{2+}$ ions are hydrated, so when they are adsorbed, water molecules will be released and dispersed in the solution, which leads to entropy increase along with system randomness.

\subsection{Composite Surface Design Methods}

The experimental data are presented in Table 4 . The adsorption efficiency ranged from $31 \%$ to $100 \%$, which indicates a significant effect of the experimental conditions on CMK-3 performance. 
Table 4. Response: actual and predicted values.

\begin{tabular}{|c|c|c|c|c|c|}
\hline \multirow{3}{*}{ Run } & \multirow{3}{*}{$\begin{array}{c}\text { Variable } 1 \\
\text { Concentration } \\
\mathrm{mg} / \mathrm{L}\end{array}$} & \multirow{3}{*}{$\begin{array}{c}\text { Variable } 2 \\
\text { Temperature } \\
\text { deg. C } \\
\end{array}$} & \multirow{3}{*}{$\begin{array}{c}\text { Variable } 3 \\
\text { Mass } \\
\text { mg }\end{array}$} & \multirow{2}{*}{\multicolumn{2}{|c|}{$\begin{array}{c}\text { Response } \\
\text { Adsorption \% }\end{array}$}} \\
\hline & & & & & \\
\hline & & & & Actual & Predicted \\
\hline 1 & 0 & 1 & 1 & 85.6 & 87.95 \\
\hline 2 & -1 & -1 & 0 & 96.4 & 94 \\
\hline 3 & 1 & -1 & 1 & 50 & 49.21 \\
\hline 4 & -1 & 0 & 1 & 100 & 98.95 \\
\hline 5 & 1 & -1 & 0 & 42.26 & 42.62 \\
\hline 6 & 1 & -1 & -1 & 31.5 & 31.07 \\
\hline 7 & 0 & -1 & 0 & 73.9 & 79.22 \\
\hline 8 & 1 & 1 & 0 & 46.9 & 51.29 \\
\hline 9 & 1 & 0 & -1 & 33 & 35.21 \\
\hline 10 & 0 & -1 & 1 & 81 & 85.24 \\
\hline 11 & 0 & -1 & -1 & 68.4 & 67.95 \\
\hline 12 & -1 & -1 & 1 & 100 & 99.64 \\
\hline 13 & -1 & 0 & -1 & 72.1 & 83.41 \\
\hline 14 & -1 & 1 & -1 & 76 & 85.08 \\
\hline 15 & 0 & 0 & -1 & 70.7 & 69.90 \\
\hline 16 & 0 & 1 & 0 & 80 & 83.51 \\
\hline 17 & 0 & 0 & 0 & 78 & 80.78 \\
\hline 18 & -1 & 1 & 0 & 100 & 95.37 \\
\hline 19 & -1 & -1 & -1 & 88.4 & 82.92 \\
\hline 20 & 0 & 1 & -1 & 90 & 73.03 \\
\hline 21 & 1 & 0 & 0 & 49.8 & 46.37 \\
\hline 22 & -1 & 1 & 1 & 100 & 99.44 \\
\hline 23 & 1 & 1 & 1 & 55 & 56.30 \\
\hline 24 & 1 & 1 & -1 & 39 & 40.53 \\
\hline 25 & 1 & 0 & 1 & 57.3 & 52.17 \\
\hline 26 & -1 & 0 & 0 & 100 & 94.10 \\
\hline 27 & 0 & 0 & 1 & 86 & 86.01 \\
\hline
\end{tabular}

\subsection{Analysis of Variance (ANOVA)}

ANOVA or variance analysis is a statistical test to figure out if the experimental results are significant or not, and if there is a difference between the studied groups. More specifically, the ANOVA test helps one to know if the null hypothesis should be rejected or accepted. In addition, the $p$-value is used to determine the significance of the results. It is a number between 0 and 1 . If the $p$-value $\leq 0.05$, the null hypothesis (that the studied variable has no effect on adsorption process) is rejected. On the other hand, the F-test involves the ratio of two variances that are a measure of dispersion, and larger values represent greater dispersion. The obtained ANOVA results are given in Table 5. The model F-value is 31.53, which implies its significance. A, C and $\mathrm{A}^{2}$ are significant model terms, since their $p$-values are smaller than 0.05 . Values greater than 0.1 indicate the model terms are not significant. It was found that the solution concentration has the greatest effect on adsorption with the highest F-value of 231.66, which confirms further the previously obtained experimental data. Copper ion concentration and adsorbent mass affected the adsorption process greatly, while temperature had a lesser effect. This could be attributed to the high efficiency of CMK-3 for $\mathrm{Cu}^{2+}$ adsorption, so increasing the temperature did not extensively affect the adsorption capacity. 
Table 5. Estimated regression coefficients for response surface model.

\begin{tabular}{cccc}
\hline Source & F-Value & $p$-Value & Standard Error \\
\hline Model & 31.53 & $<0.0001$ & 3.65 \\
A-concentration & 231.66 & $<0.0001$ & 1.56 \\
B-temperature & 2.18 & 0.1577 & 1.57 \\
C-mass & 27.42 & $<0.0001$ & 1.55 \\
AB & 0.94 & 0.3458 & 1.88 \\
AC & 0.037 & 0.8506 & 1.85 \\
BC & 0.10 & 0.7542 & 1.86 \\
$\mathrm{~A}^{2}$ & 4.58 & 0.0471 & 2.81 \\
$\mathrm{~B}^{2}$ & 0.048 & 0.8293 & 2.68 \\
$\mathrm{C}^{2}$ & 4.07 & 0.0596 & 3.07 \\
\hline
\end{tabular}

The Studentized residual in statistics is used for the quotient that results from the division of a residual by an estimate of its standard deviation. The statistical plots were applied to understand whether the model gives a good approximation of the real system or not [19]. The normal probability plots of the Studentized residuals are shown in Figure 6a. The obtained data points follow a straight line, which indicates that the residuals follow a normal distribution. Figure $6 \mathrm{~b}$ proves that the predicted values for copper adsorption estimated by the model and the actual experimental data are in agreement, proving the reliability of the regression model.

\subsection{Effect of the Studied Parameters on Copper Adsorption}

The 2D and 3D surface response plots were used to analyze the relationships between the studied factors and copper removal efficiency by CMK-3 by keeping one factor constant at level 0 and varying the other two (Figure 7). The plots confirm that as mass and temperature increase, copper adsorption increases. On the other hand, as concentration increases, copper adsorption percentage decreases and the adsorption capacity increases, as explained earlier. The decreased efficiency at higher concentration is due to the saturation of the available sites on the CMK-3 surface. Finally, as temperature increases along with mass, copper adsorption increases as well, so copper adsorption on CMK-3 becomes increased with temperature.
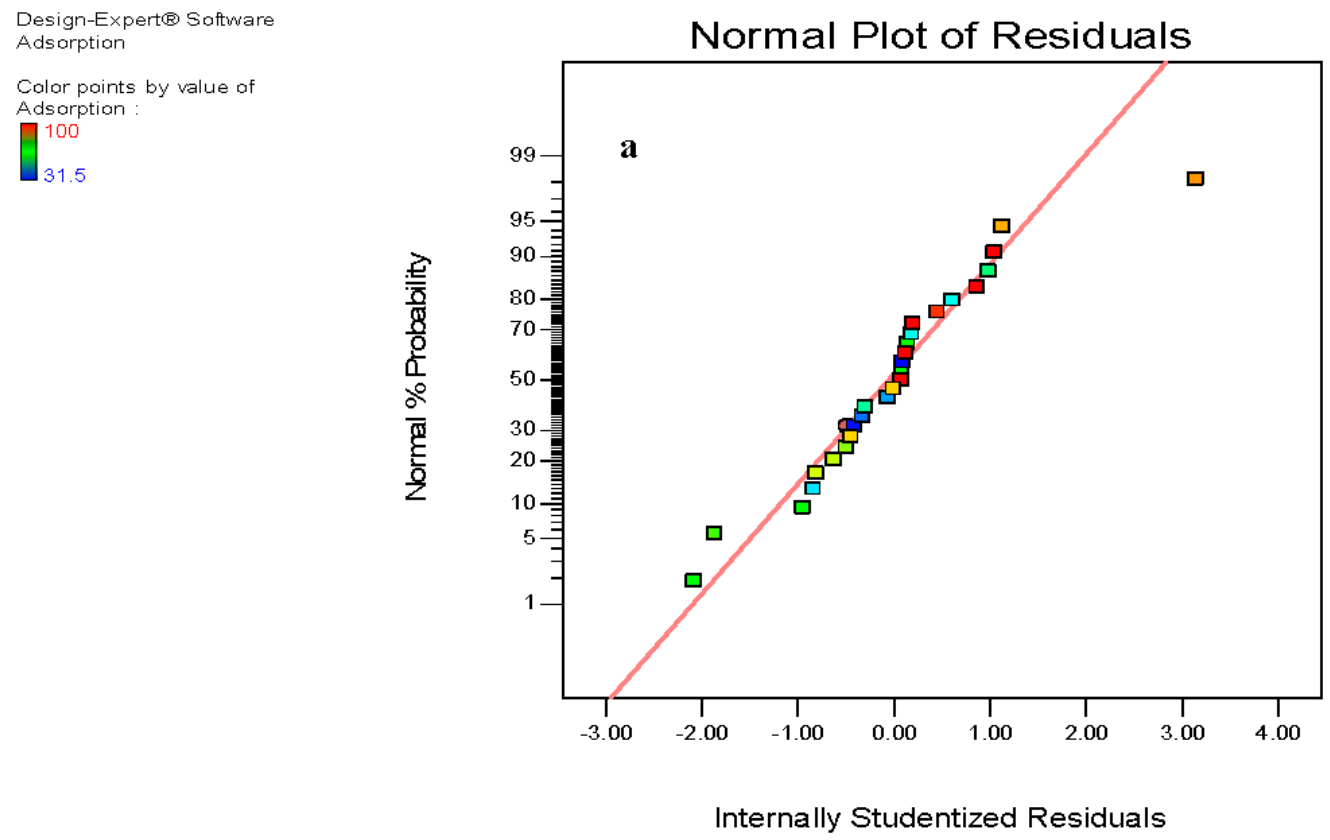

Figure 6. Cont. 
Design-Expert@ Software Adsorption

Color points by value of Adsorption

100

31.5

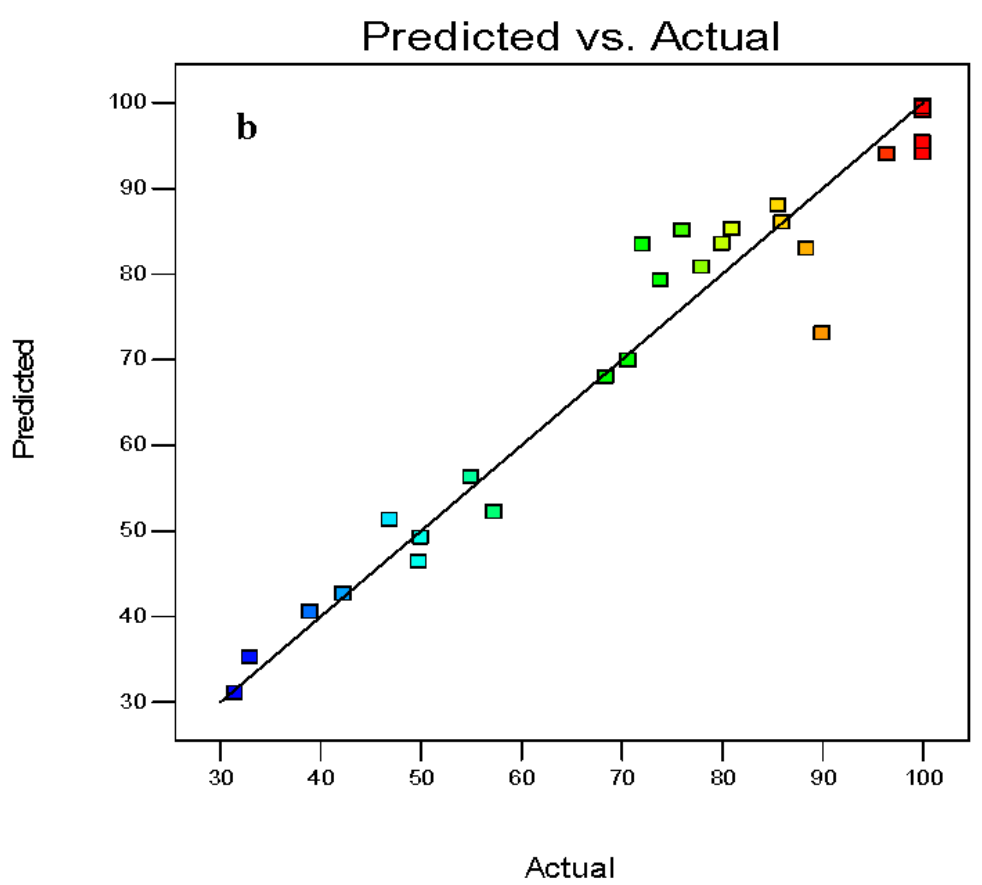

Figure 6. Normal percent probability versus internally Studentized residuals (a) and comparison of model predictions of adsorption with the experimental data $(\mathbf{b})\left(R^{2}=0.899\right)$.

It is worth mentioning that the maximum adsorption capacities reported in the literature using microporous activated carbon are lower than those obtained in this study (Table 6). This makes CMK-3 a very promising adsorbent for heavy metal removal from wastewater.

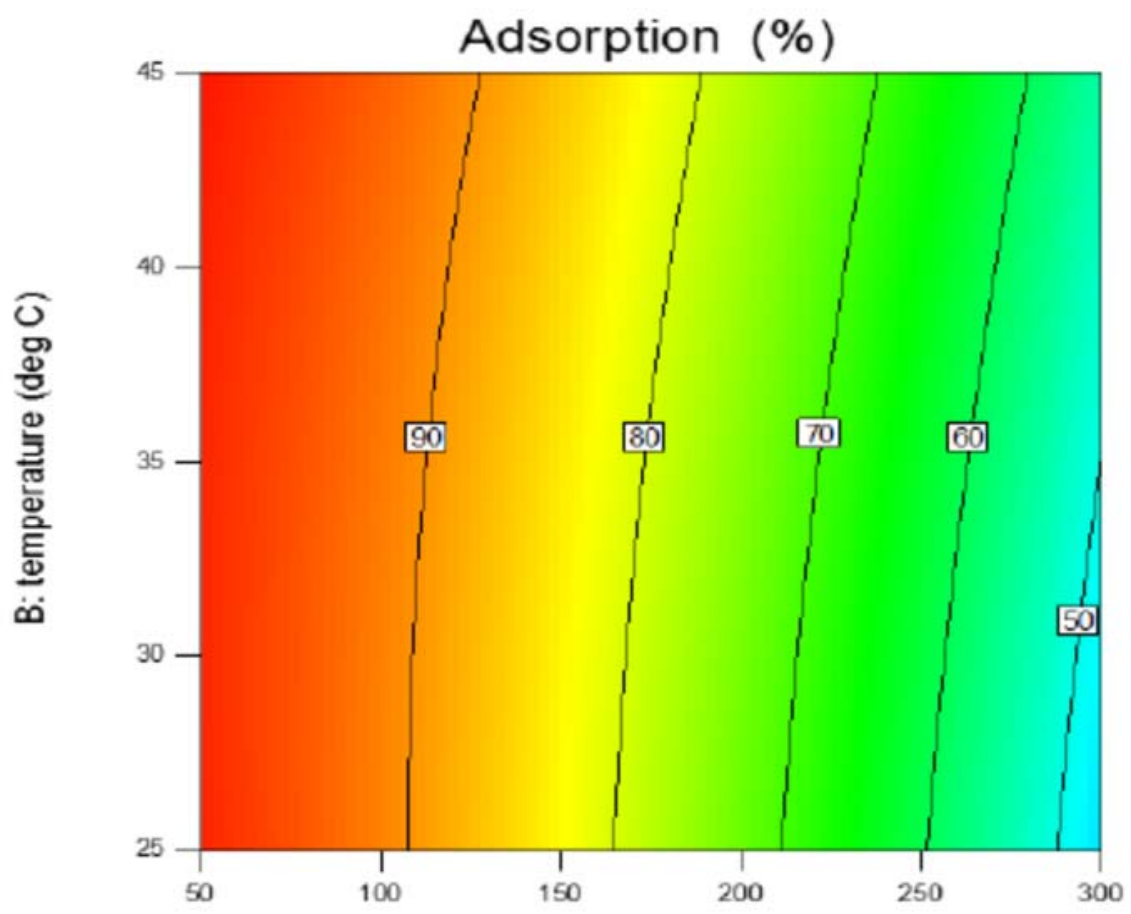

A: Concentration $(\mathrm{mg} / \mathrm{L})$

Figure 7. Cont. 

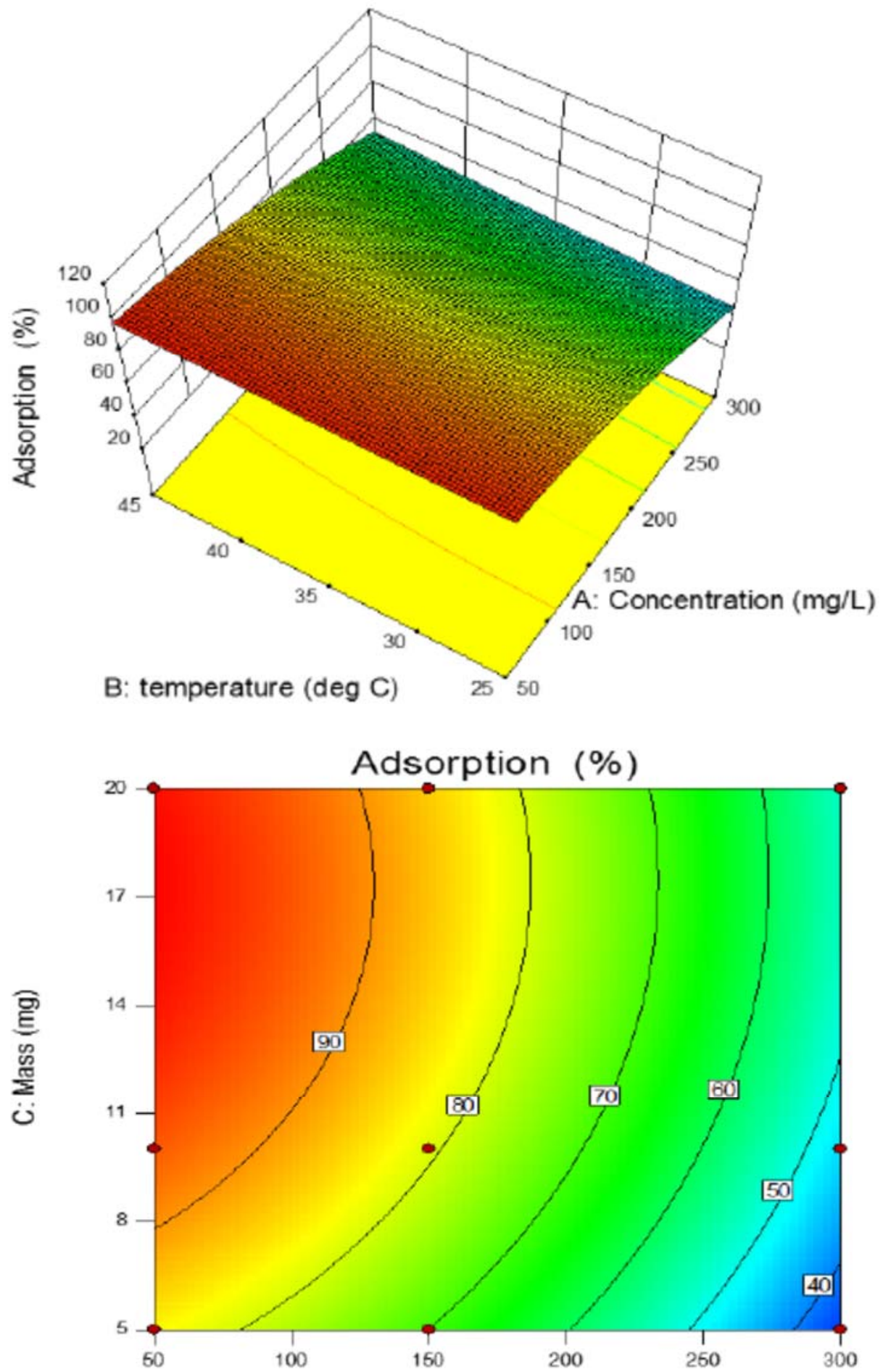

A: Concentration (mg/L)

Figure 7. Cont. 

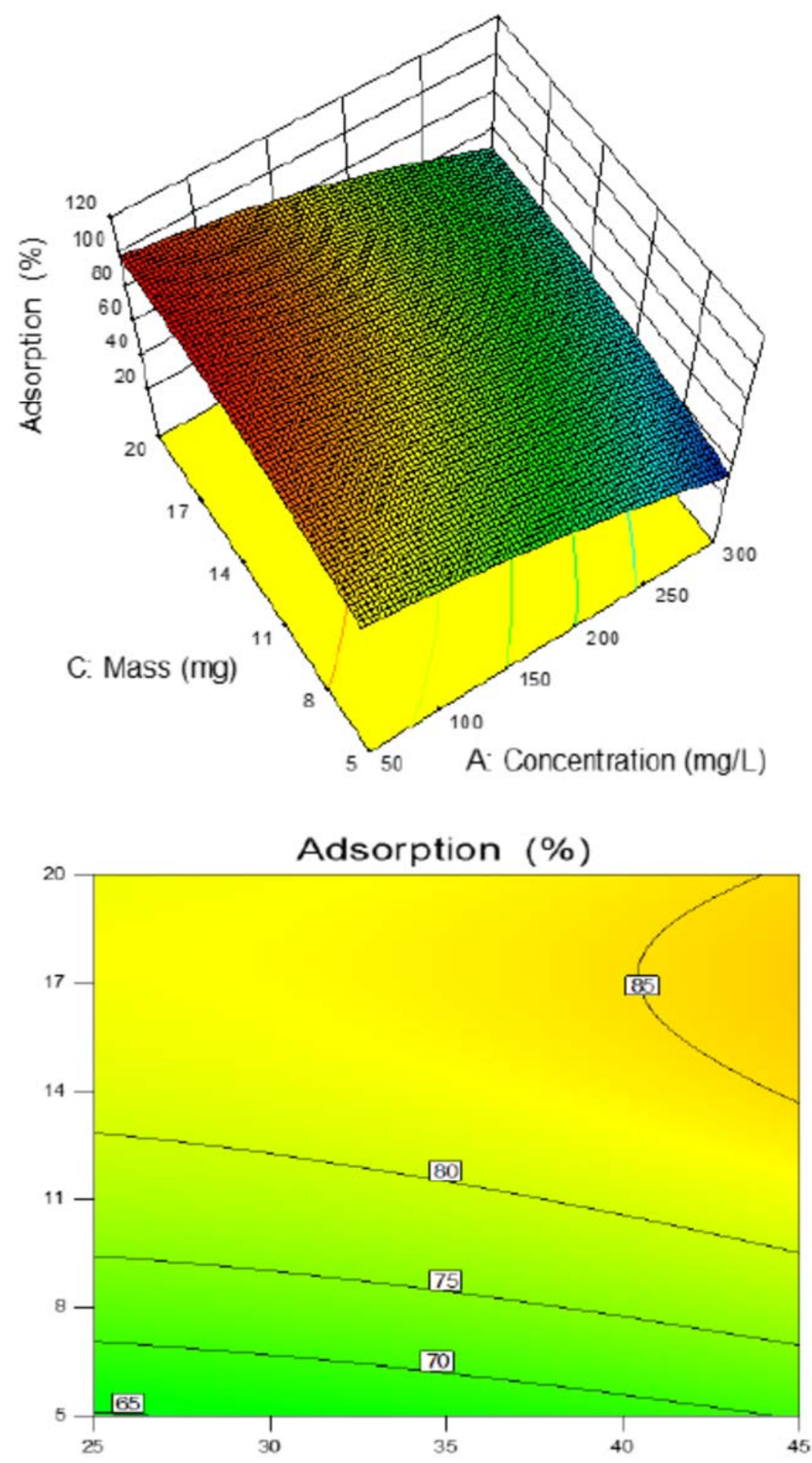

B: temperature (deg C)

Figure 7. Cont. 


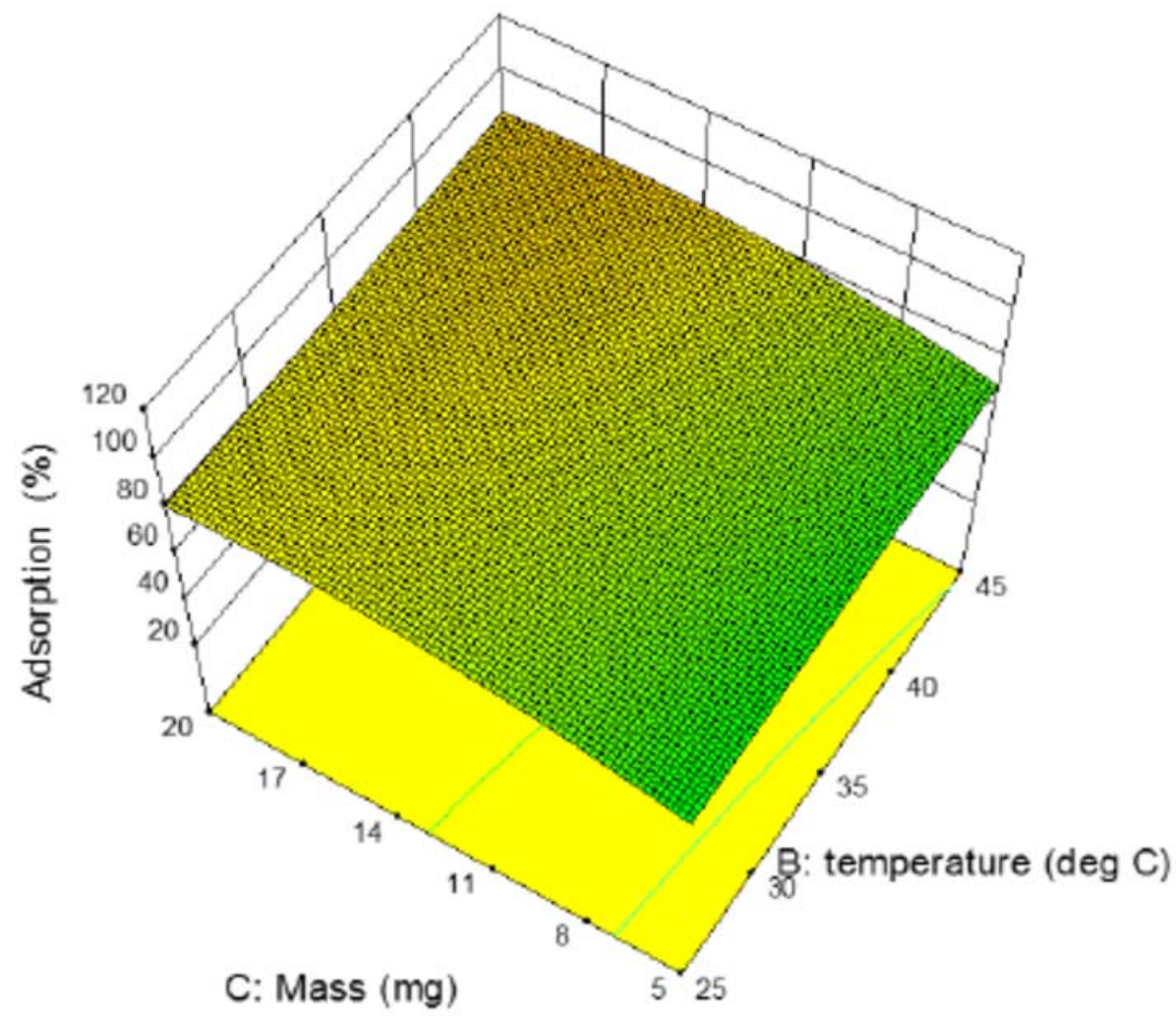

Figure 7. 2D and 3D surface response plots of the quadratic model for copper adsorption on CMK-3 (hold values: $\mathrm{M}=10 \mathrm{mg}, \mathrm{T}=35^{\circ} \mathrm{C}, \mathrm{C}=150 \mathrm{ppm}$ ).

Table 6. Heavy metal adsorption on activated carbon (AC).

\begin{tabular}{|c|c|c|c|c|}
\hline Carbon & Modification Route & MetalIons & $\begin{array}{c}\text { Adsorption } \\
\text { Capacity }\left(\mathrm{mg} \cdot \mathrm{g}^{-1}\right)\end{array}$ & Ref. \\
\hline AC from hazelnut husks & Zinc chloride activation & $\begin{array}{l}\mathrm{Cu}^{2+} \\
\mathrm{Pb}^{2+}\end{array}$ & $\begin{array}{c}6.64 \\
13.05\end{array}$ & {$[20]$} \\
\hline $\begin{array}{l}\text { AC from Ceiba } \\
\text { pentandra hulls }\end{array}$ & Steam activation (SA) & $\begin{array}{l}\mathrm{Cu}^{2+} \\
\mathrm{Cd}^{2+}\end{array}$ & $\begin{array}{l}20.8 \\
19.5\end{array}$ & [21] \\
\hline Commercial AC & $\begin{array}{c}\text { Sodium diethyl } \\
\text { dithiocarbamate (SDDC) }\end{array}$ & $\mathrm{Cu}^{2+}$ & 38.9 & [22] \\
\hline AC from grape bagasse & Phosphoric acid & $\mathrm{Cu}^{2+}$ & 43.47 & {$[23]$} \\
\hline CMK-3 & - & $\mathrm{Cu}^{2+}$ & 250 & This study \\
\hline
\end{tabular}

\section{Conclusions}

SBA-15 was used as a mold to synthesize CMK-3 mesoporous carbon. Then, its performance for $\mathrm{Cu}^{2+}$ adsorption was studied under several experimental conditions including metal ion concentration, adsorbent mass and temperature. The analysis of the response surface design model confirmed that the studied factors have a significant effect on copper adsorption capacity on CMK-3, with the concentration being the most important one. The obtained model was significant and can be used to predict copper adsorption efficiency on CMK-3.

Author Contributions: Z.E. conceived the work and performed the experiments; Z.E., I.B.-G. and Y.P. analyzed the data; Z.E. wrote the manuscript, Y.P. managed the study and the unit research in Poitiers.

Funding: This research was funded by Poitiers university grant number, 1 .

Acknowledgments: The authors are thankful to the (IC2MP) 'Institut de Chimie des Milieux et Matériaux de Poitiers-UMR 7285', Poitiers University, PRES for the financial support of this work. 
Conflicts of Interest: The authors declare no conflict of interest.

\section{References}

1. Ezzeddine, Z.; Batonneau-Gener, I.; Pouilloux, Y.; Hamad, H.; Saad, Z. Synthetic Nax Zeolite as a Very Efficient Heavy Metals Sorbent in Batch and Dynamic Conditions. Colloids Interfaces 2018, 2, 22. [CrossRef]

2. Cheng, H.P.; Su, L.C.; Chen, C.Y. Thermodynamics and kinetics of adsorption of Cu (II) onto waste iron oxide. J. Hazard. Mater. 2007, 144, 406-411. [CrossRef]

3. Hamad, H.; Ezzeddine, Z.; Kanaan, S.; Lakis, F.; Hijazi, A.; Moussawi, M.A. A Novel Modification and Selective Route for the Adsorption of $\mathrm{Pb}^{2+}$ by oak charcoal functionalized with Glutaraldehyde. Adv. Powder Technol. 2016, 27, 631-637. [CrossRef]

4. Bailey, S.E.; Olin, T.J.; Bricka, R.M.; Adrian, D.D. A review of potentially low-cost sorbents for heavy metals. Water Res. 1999, 33, 2469-2479. [CrossRef]

5. Hamad, H.; Ezzeddine, Z.; Lakis, F.; Rammal, H.; Srour, M.; Hijazi, A. An Insight into the Removal of Cu (II) and $\mathrm{Pb}$ (II) by Aminopropyl Modified Mesoporous Carbon CMK-3: Adsorption capacity and mechanism. Mater. Chem. Phys. 2016, 178, 57-64. [CrossRef]

6. Liang, C.D.; Li, Z.J.; Dai, S. Mesoporous Carbon Materials: Synthesis and Modification. Angew. Chem. Int. Ed. 2008, 47, 3696-3717. [CrossRef] [PubMed]

7. Ezzeddine, Z.; Batonneau-Gener, I.; Pouilloux, Y.; Hamad, H. Removal of Methylene Blue by Mesoporous CMK-3: Kinetics, Isotherms and Thermodynamics. J. Mol. Liq. 2016, 223, 763-770. [CrossRef]

8. Qiang, Z.; Gurkan, B.; Ma, J.; Liu, X.; Guo, Y.; Cakmak, M.; Cavicchi, K.A.; Vogt, B.D. Roll-to-roll fabrication of high surface area mesoporous carbon with process-tunable pore texture for optimization of adsorption capacity of bulky organic dyes. Micropor. Mesopor. Mater. 2016, 227, 57-64. [CrossRef]

9. Qiang, Z.; Guo, Y.; Liu, H.; Cheng, S.Z.D.; Cakmak, M.; Cavicchi, K.A.; Vogt, B.D. Large-Scale Roll-to-Roll Fabrication of Ordered Mesoporous Materials using Resol-Assisted Cooperative Assembly. ACS Appl. Mater. Interfaces. 2015, 7, 4306-4310. [CrossRef] [PubMed]

10. Zhang, Y.; Qiang, Z.; Vogt, B.D. Relationship between crosslinking and ordering kinetics for the fabrication of soft templated (FDU-16) mesoporous carbon thin films. RSC Adv. 2014, 4, 44858-44867. [CrossRef]

11. Moreno-Tovara, R.; Terrésb, E.; Rene Rangel-Mendez, J. Oxidation and EDX elemental mapping characterization of an ordered mesoporous carbon: $\mathrm{Pb}(\mathrm{II})$ and $\mathrm{Cd}(\mathrm{II})$ removal. Appl. Surf. Sci. 2014, 303, 373-380. [CrossRef]

12. Moradi, S.E.; Baniamerian, M.J. Applications of chemically modified ordered mesoporous carbon as solid phase extraction sorbent for preconcentration of trace lead ion in water samples. Chem. Ind. Chem. Eng. Q. 2011, 17, 397-408. [CrossRef]

13. Zhao, D.; Huo, Q.; Feng, J.; Chmelka, B.; Stucky, G. Nonionic Triblock and Star Diblock Copolymer and Oligomeric Surfactant Syntheses of Highly Ordered, Hydrothermally Stable, Mesoporous Silica Structures. J. Am. Chem. Soc. 1998, 120, 6024-6036. [CrossRef]

14. Vinu, A.; Srinivasu, P.; TakahashI, M.; Mori, T.; Balasubramanian, V.V.; Ariga, K. Controlling the textural parameters of mesoporous carbon materials. Micropor. Mesopor. Mater. 2007, 100, 20-26. [CrossRef]

15. Zhao, D.; Feng, J.; Huo, Q.; Melosh, N.; Fredrickson, G.H.; Chmelka, B.F.; Stucky, G.D. Triblock Copolymer Syntheses of Mesoporous Silica with Periodic 50 to 300 Angstrom Pores. Science 1998, 279, 548-552. [CrossRef] [PubMed]

16. Thuan, T.V.; Phuong Quynh, B.T.; Nguyen, T.D.; Thanh Ho, V.T.; Bach, L.G. Response surface methodology approach for optimization of $\mathrm{Cu}^{2+}, \mathrm{Ni}^{2+}$ and $\mathrm{Pb}^{2+}$ adsorption using $\mathrm{KOH}$-activated carbon from banana peel. Surfaces Interfaces 2017, 6, 209-217. [CrossRef]

17. Cuppett, J.D.; Duncan, S.E.; Dietrich, A.M. Evaluation of Copper Speciation and Water Quality Factors That Affect Aqueous Copper Tasting Response. Chem. Senses 2006, 31, 689-697. [CrossRef] [PubMed]

18. Jing, X.; Liua, F.Q.; Yanga, X.; Linga, P.; Li, L.J.; Long, C.; Li, A.M. Adsorption performances and mechanisms of the newly synthesized $N, N$-di(carboxymethyl) dithiocarbamate chelating resin toward divalent heavy metal ions from aqueous media. J. Hazard. Mater. 2009, 167, 589-596. [CrossRef] [PubMed]

19. Da'na, E.; Sayari, A. Effect of regeneration conditions on the cyclic performance of amine-modified SBA-15 for removal of copper from aqueous solutions: Composite surface design methodology. Desalination 2011, 277, 54-60. [CrossRef] 
20. Imamoglu, M.; Tekir, O. Removal of copper (II) and lead (II) ions from aqueous solutions by adsorption on activated carbon from a new precursor hazelnut husks. Desalination 2008, 228, 108-113. [CrossRef]

21. Madhava Rao, M.; Ramesh, A.; Purna Chandra Rao, G.; Seshaiah, K. Removal of copper and cadmium from the aqueous solutions by activated carbon derived from Ceiba pentandra hulls. J. Hazard. Mater. 2006, 129, 123-129. [CrossRef] [PubMed]

22. Monser, L.; Adhoum, N. Modified activated carbon for the removal of copper, zinc, chromium and cyanide from wastewater. Sep. Purif. Technol. 2002, 26, 137-146. [CrossRef]

23. Demiral, H.; Güngör, C. Adsorption of copper(II) from aqueous solutions on activated carbon prepared from grape bagasse. J. Clean. Prod. 2016, 124, 103-113. [CrossRef]

(C) 2018 by the authors. Licensee MDPI, Basel, Switzerland. This article is an open access article distributed under the terms and conditions of the Creative Commons Attribution (CC BY) license (http:/ / creativecommons.org/licenses/by/4.0/). 